\title{
Community Perspectives on the Benefits of Students Teaching Practice in Tertiary Institutions in Southern Nigeria
}

\author{
Asiyai, Romina Ifeoma \\ Department of Educational Administration and Policy Studies \\ Faculty of Education, Delta State University Abraka, Nigeria \\ Email: asiyairomina@yahoo.com
}

Doi:10.5901/jesr.2016.v6n3p159

\begin{abstract}
This study examined students teaching practice in tertiary institutions in southern Nigeria. The purpose of the study was to find out the perceptions of student teachers, mentors of cooperating schools, and community members regarding the benefits of students teaching practice. The study provided answers to three research questions. The sample of the study comprised student teachers, who were randomly selected from two levels of study, school heads and teachers of cooperating schools (mentors) and community members drawn through stratified random sampling technique. The sample was selected from three universities and two colleges of education in south-west geopolitical zones of Nigeria. The survey research adopted ex-postfacto design. Qualitative and quantitative methods were used for data collection. Data collected were analyzed through descriptive statistics tools. The findings indicates that student teachers, mentors of cooperating schools and community members perceived teaching practice as beneficial to them in numerous ways. The study recommends that teaching practice should be given more encouragement in view of its numerous benefits.
\end{abstract}

Keywords: Benefits, community members, mentors, student teachers, teaching practice

\section{Introduction}

Teaching practice is an integral component of teacher education programme. It is a period of professional socialization during which trainee teachers learn the rudiments of teaching through active involvement in the practice of real life teaching, so as to enhance their sustainability in the teaching profession. Teaching practice has been associated with such terms like field studies, infield experience, school base experience or internship (Taneja, 2000). Teaching practice is similar to Students Industrial Works Experience (SIWES) in the Arts, Court attachment in the legal profession, Houseman ship in the medical profession and Industrial Training as in the Arts and Engineering. During teaching practice, student teachers are sent to schools to observe teaching from cooperating school teachers and practice teaching so that they can acquire teaching skills, learns teaching strategies and effective classroom management techniques. It is a skill development exercise, a kind of clinical therapy designed to diagnose and remediate professional teachers' competence and deficiencies (Ogunbameru and Uwameiye, 2012). According to DeVille (2010), practical teaching affords students teachers the opportunity to reflect not just on matters associated with their professional growth, but on who they are and what they would become in the future. Practical teaching brings student teachers into a programme of cooperative and interactive guidance by experienced teachers (Young and Edwards, 2006). It is the time when student teachers face teaching in real life situation and evaluate their teaching as they socialize with their mentors, other teachers, their lecturers and through self-reflection. Teaching practice affords student teachers the opportunity to apply the pedagogy knowledge gained in lecture rooms in real classroom situations (Mudzielwana and Maphosa, 2014).

As rightly noted by Fafunwa cited in Olulobe (2007), for a country to develop educationally, there must be emphasis on teacher education because with a well trained teaching cadre, a country can have a place educationally in the committee of nations. Fafunwa argued that since education is the door to socio-cultural development, teachers hold the key to the door and are therefore great builders of national development. Ehindero cited in Bolarfinwa (2011) sees teaching as one of the most influential profession in the society. Ehindero maintained that teachers in their day to day work can and do make a huge difference to children's lives directly through the curriculum they teach and indirectly through their behavior, attitudes, relationships and values with an interest in pupils. 


\section{Purpose of the Study}

1. To find out the perception of student teachers on the benefits of their teaching practice exposure.

2. To find out the perceptions of cooperating school heads and teachers of the benefits of student teachers' teaching practice exercise to them if any.

3. To find out from community members the benefits of students teaching practice to the community.

\section{Research Questions}

1. What are the benefits of teaching practice as perceived by student teachers in universities in Nigeria?

2. What are the benefits of teaching practice as perceived by mentor teachers in cooperating schools?

3. What are the benefits of teaching practice as perceived by community members?

\section{Theoretical Framework and Literature Review}

This study is hinged on social constructivism theory propounded by Vygotsky (1962). This theory claim that the personal construction of knowledge always occur in social contexts, since learning activities are socially and contextually bound. The social constructivism perspective in learning sees learning as an active process of constructing meanings and transforming understandings during interaction with the environment. Learners should play an active role in constructing knowledge as learning is collaborative and learners learn from mentors and one another. There should be a continuous reciprocal interaction to ensure that the learning process is productive and successful. This approach is in favour of student-centered teaching and learning and places the learners' own efforts to understand at the centre of the educational events (Tschannen \& Woolfolk 2007).

Social constructivism believes that learners should deal with complex real-life situations. They need ample opportunity to engage in meaningful problem based activities. Student teachers therefore need to plan and present lessons and manage disruptive behavior and administrative tasks during teaching practice. When planning and presenting lessons, students are led to apply knowledge in diverse and authentic contexts to explain ideas, interpret text and construct arguments based on evidence. They continually need to articulate their knowledge and understanding and consult various resources. Students should also work collaboratively and support one another in task-oriented dialogue. Supporters of the socio constructivists approach emphasize that mentors make their own thinking processes explicit to students and encourage them to do the same through dialogue, drawings and writing. Mentors employ a variety of assessment strategies although self-assessment is also encouraged.

There is plethora of studies conducted on students' teaching practice. In terms of benefits of teaching practice, Andabai (2013) found that teaching practice impacted immensely on student teachers of Niger Delta University as they were able to try out ideas and theory in practice, plan, prepare and present lessons, understand the principles of child development and growth, broaden their knowledge of subject matter and use of instructional materials. Teaching practice is capable of shaping the student teachers' perceptions and understanding of teaching and learning (Mudzielwana and Maphosa, 2014). During teaching practice, the experienced teachers or mentors play pivotal roles in student teachers' professional growth (Barry and Lang, 2002; Mudzielwana and Maphosa, 2014). Teaching practice period is an opportunity for mentors and supervisors to gather information about pre-service teachers' personal capabilities for teaching as well as test their beliefs about teaching (Katrina, 2004).

Student teachers during teaching practice are expected to apply the theories they acquired at lectures in their institutions into practice and thereby develop a deeper understanding of educational principles and how to implement them for effective learning (Farauta and Amuche, 2013). According to $F \quad$ errier-Kerr (2009), teaching practice give an opportunity for trainee teachers to gain insight into how qualified teachers operate in their classroom practice. Putnam and Borko (2000) assert that the most important aspect of teaching practice is professional socialization. Thus, as student teachers socialize by interacting with their colleagues from other schools, mentors, school heads and other staff members, sustainable inter personal relationships could be developed, from which student teachers could receive additional professional supports. For teaching and learning to occur, teachers need opportunity to participate in professional communities that discuss learning theories, various teacher materials and pedagogy (Wenzlaff and Weseman 2011; Mudzielwana and Maphosa 2014). Through such professional communities, student teachers can learn and improve in their knowledge of subject matter, knowledge of pedagogy, curriculum knowledge, and knowledge of 
classroom management, knowledge of innovative instructional strategies and pedagogical content knowledge for better professional practice.

\section{Methodology}

\subsection{Population of the Study}

The population of the study comprised all the universities and their affiliated colleges of education in Delta and Edo states of Nigeria during the 2014/2015 academic year. All the 300 and 400 level students of the faculty of education, their lecturers, teachers and school heads of cooperating schools and students.

\subsection{Sample and Sampling Technique}

A sample of 200 students made up of 100 (300 level) and 100 (400 level) was selected via the random sampling technique and 80 teachers of cooperating schools and 40 school heads ( 20 from primary school and 20 from secondary school) and 60 members of the community selected through the stratified sampling technique in urban and rural locations of Delta and Edo states of Nigeria where the student teachers had their teaching practice exercise. The overall sample size is 380. The sample was selected from Ambrose Ali University Ekpoma, Delta State University Abraka, University of Benin, Benin-City, College of Education Agbor and College of Education Warri. The two Colleges of Education are running degree programmes.

\subsection{Instrument for Data Collection}

Data for this study consists of both primary and secondary data. The primary source of data collection was the interview. The interview was considered appropriate because through the use of interview, the respondents feel relaxed and were able to express themselves about the phenomenon being investigated. The interview questions were later transmitted into questionnaire for ease of quantitative analysis of data. The questionnaire comprised two main parts namely $A$ and $B$. The first part (A) contained demographic variables of respondents eliciting information pertaining to their gender, status and school location. The second part (B) contained twenty-seven items, divided into three sub sections. The first sub division contained seven items entitled "Student Teachers Perceptions on the Benefits of Teaching Practice Questionnaire (STPBTPQ)" meant to answer research question one. The second sub division contained eleven items entitled "Cooperating School Heads and Teachers Perceptions on the Benefits of Teaching Practice Questionnaire (CSHTPBTPQ)" meant to answer research question two. The third sub division contained nine items entitled "Community Members Perceptions on the Benefits of Teaching Practice Questionnaire (CMPBTPQ)" meant to answer research questions three. The items were all structured on a four point rating scale, ranging from strongly agrees to strongly disagree.

\subsection{Administration of the Instrument}

The instrument was administered by the researcher and three persons who assisted her. For the student teacher questionnaire, two hundred copies were administered but one hundred and ninety-two were retrieved valid for analysis of data. For mentor questionnaire, one hundred and twenty copies were administered but one hundred and five was retrieved valid for data analysis. For the questionnaire for community members, sixty copies were administered and all were retrieved valid and used for analysis of data.

\subsection{Method of Data Analysis}

Data for this study were analyzed through the use descriptive statistics such as frequency count and percent. The cut-off point of 2.50, the mid-point of the score was used in making decision as to whether to accept the item as agreed or not to accept the item as disagreed. Consequently, items having mean score from 2.50 and above were accepted as agreed $(+)$ while items with mean score below 2.50 were not accepted and hence regarded as disagreed (-). 


\section{Results}

The results of data analysis for the study are presented in tables 1-4 below:

Table 1: Benefits of teaching practice as perceived by student teachers

\begin{tabular}{|c|c|c|c|c|c|}
\hline $\mathrm{S} / \mathrm{N}$ & Items & Score & $\%$ Agree & $\%$ Dis & Remark \\
\hline 1 & Teaching practice has helped me to improve in communicative skills & 724 & 92 & 08 & + \\
\hline 2 & $\begin{array}{l}\text { Through daily writing of lesson plan and notes, and writing on the white boards during } \\
\text { teaching practice my writing skills has improved }\end{array}$ & 698 & 89 & 11 & + \\
\hline 3 & Teaching practice has exposed me to the rudiments of teaching & 677 & 86 & 14 & + \\
\hline 4 & Teaching practice gives me a sense of accomplishment & 770 & 98 & 02 & + \\
\hline 5 & It improved my confident in speaking & 764 & 97 & 03 & + \\
\hline 6 & $\begin{array}{l}\text { By observing my mentor teach during teaching practice, my knowledge of teaching } \\
\text { methods improved }\end{array}$ & 570 & 71 & 29 & + \\
\hline 7 & It has helped me to be positively disposed to the teaching profession & 700 & 89 & 11 & + \\
\hline 8 & The feedbacks I received from mentors has improved my teaching effectiveness & 710 & 90 & 10 & + \\
\hline 9 & $\begin{array}{l}\text { Teaching practice has broaden my knowledge of how to keep school records such as } \\
\text { dairy and attendance register }\end{array}$ & 520 & 66 & 34 & + \\
\hline 10 & $\begin{array}{l}\text { It has helped me to know how to relate what I was taught during lectures to practice in } \\
\text { real life situation }\end{array}$ & 476 & 61 & 39 & + \\
\hline 11 & $\begin{array}{l}\text { It has helped to broaden my knowledge of how to apply teaching and learning principles } \\
\text { during instruction in classroom situation }\end{array}$ & 566 & 72 & 28 & + \\
\hline
\end{tabular}

The results in table 1 showed that the mean value for all the items exceeded 2.50 the cut-off score. This indicates an overwhelming agreement by student teachers that all the items are the benefits of teaching practice.

Table 2: Benefits of teaching practice as perceived by cooperating school heads and teachers (mentors)

\begin{tabular}{|c|l|c|c|c|c|}
\hline S/N & Items & Score & $\%$ Agree & $\%$ Dis & Remark \\
\hline 1 & Collaborating with student teachers can enhance personal development of mentors & 440 & 78.6 & 21.4 & + \\
\hline 2 & Working with student teachers can help to improve interpersonal skills of mentors & 390 & 69.6 & 30.4 & + \\
\hline 3 & Mentors and school heads can derive pleasure from helping novice teachers grow & 480 & 85.7 & 14.2 & + \\
\hline 4 & Helping novice teachers by counseling them can bring satisfaction & 466 & 83.2 & 16.7 & + \\
\hline 5 & $\begin{array}{l}\text { Mentors can be relieved of some of their excess workloads by student teachers in } \\
\text { their subject areas during teaching practice }\end{array}$ & 420 & 71.2 & 28.8 & + \\
\hline 6 & $\begin{array}{l}\text { Professional development of mentors can be enhanced by working with student } \\
\text { teachers and reflecting on their teaching }\end{array}$ & 450 & 83.4 & 19.6 & + \\
\hline 7 & $\begin{array}{l}\text { It can enhance the development of sustainable inter-personal relationship between } \\
\text { mentors and mentees (student teachers) }\end{array}$ & 486 & 86.2 & 13.8 & + \\
\hline
\end{tabular}

The data in table 2 showed that for all the items, cooperating school heads and teachers who acted as mentors during teaching practice exercise overwhelmingly agreed that all the items are the benefits of teaching practice to them. 
Table 3: Benefits of teaching practice as perceived by community members

\begin{tabular}{|c|c|c|c|c|c|}
\hline S/N & Items & Score & $\%$ Agree & $\%$ Dis & Remark \\
\hline 1 & $\begin{array}{l}\text { Collaborating with student teachers can enhance personal development of members of the } \\
\text { community }\end{array}$ & 250 & 69.4 & 30.6 & + \\
\hline 2 & $\begin{array}{l}\text { Student teachers can help to improve reading and communicative skills of children of } \\
\text { community members when they socialize by involvement in extra-curricular activities like } \\
\text { debate, drama, quize, sporting and cultural dance }\end{array}$ & 225 & 62.5 & 37.5 & + \\
\hline 3 & $\begin{array}{l}\text { Community members can get educational benefits in their children academic performance } \\
\text { when student teachers engage in extra mural lessons }\end{array}$ & 240 & 66.7 & 33.3 & + \\
\hline 4 & Community members can derive pleasure from helping beginning teachers grow & 259 & 71.9 & 28.1 & + \\
\hline 5 & Helping novice teachers by counseling them can bring satisfaction to community members & 286 & 79.4 & 20.5 & + \\
\hline 6 & Community members can get economic benefits when student teachers rent their houses & 299 & 83.0 & 16.9 & + \\
\hline 7 & $\begin{array}{l}\text { Community members can get economic benefits when student teachers buy food items } \\
\text { from local markets }\end{array}$ & 278 & 72.2 & 22.7 & + \\
\hline 8 & $\begin{array}{l}\text { Community members can get health benefits when student teachers carry out community } \\
\text { development projects of environmental sanitation in the community }\end{array}$ & 280 & 77.8 & 22.2 & + \\
\hline 9 & $\begin{array}{l}\text { Community members can enjoy health benefits when student teachers sensitize them } \\
\text { through giving health talks of AIDS and other deadly diseases }\end{array}$ & 275 & 78.4 & 23.6 & + \\
\hline
\end{tabular}

From Table 3, the percentage of community members who agreed with each of the item is high. This is indicative of the fact that all the items are the benefits of teaching practice to members of the community where student teachers carried out their teaching practice exercise.

\section{Discussion of Findings}

\subsection{Findings on the benefits of teaching practice as perceived by student teachers}

The findings indicated that student teachers see teaching practice as helping them to develop communicative skills; they said that teaching practice can improve their writing skills. The student teachers also said that teaching practice improved their knowledge of teaching methods when they observe their mentors teach in classroom situation, it has helped to expose them to the rudiments of teaching. They further said that teaching practice has helped them to be positively disposed to the teaching profession as well as improvement in their teaching effectiveness and improved their ability to relate theory into practice in real life. This finding agrees with Mkhasibe (2014) who noted that teaching practice increases professional growth of student teachers. The finding of this study also lends credence with Ankers, Liamas and Tomyoy cited in Adeleke et al (2011). Their finding indicates that the exposure to teaching practice made student teachers to exhibit higher level of confidence in their ability to change students' learning positively as well as increased their desire to remain in the teaching profession. In addition, the finding of this study concurs with Andabai (2013) whose finding indicates that teaching practice impacted positively on student teachers greatly since they were able to build confidence and competence in lesson preparation and developed skills and attitudes of a teacher

However, the finding of this study is at variance with that of Ogonor and Badmus (2006) who found that the orientation given to student teachers was not enough to enable them put into practice what they have learnt theoretically in classroom situation. And Bhagava (2009) whose findings showed that student teachers perceived teaching practice as a traumatic, non-educating experience, characterized by feelings of failure, stress, loss of identity, lack of self-esteem and self-confidence.

The interview report a particular student teacher has this to say "my exposure to teaching practice has made me a more effective teacher, I feel more empowered and proud to be a teacher and my expectation has gone up". Another student teacher expressed thus "teaching in the class has made me to impact positively on people and help them to solve their problems". The finding corroborates with Mostafa cited in Wambugu et al (2013). His finding indicates that teaching practice affords student teachers opportunity to develop their potentials so as to perform their future roles as teachers with lots of precision. Potentials of student teachers such as critical thinking, problem-solving skills, lesson planning skills and classroom control could be developed during teaching practice exposure (Alsaid, 2001; Bhargava \& Pathy, 2011; \& Wambulu et al, 2013). The finding also lends credence with Wambulu et al, (2013). They found that teaching practice help student teachers to become better teachers as well as afford them opportunity to reflect on their teaching. Koc (2011) noted that during teaching practice, student teachers develop teaching skills. 


\subsection{Findings on the benefits of teaching practice as perceived by mentors}

The findings on the benefits of teaching practice as expressed by mentor (school heads and teachers) indicates that mentors see collaborating with students teachers to enhance their personal development, Mentors also said that working with student teachers improved interpersonal skills. In addition, mentors said that they derive pleasure from helping novice teachers grow. They further said that it brings satisfaction as they counsel novice teachers in practice. Interestingly, the mentors also said that as they work with student teachers, they reflect on their teaching, thus enhancing their professional development. This finding is in agreement with Putnam and Borko (2000) who stressed that the most important aspect of teaching practice is professional socialization. Through such professional socialization, learning communities are formed which could enhance the professional growth and development of student teachers.

Even the interview report, a particular mentor said "it was an opportunity to increase interpersonal skills, to polish professionalism, to reflect on strategies that work best with children and to learn from the student teachers. Another mentor has to say "through teaching practice an extra pair of hands in the classroom which provided more time for special needs students" "The professional satisfaction of watching student teachers grow and develop, gives me pleasure" "The satisfaction of guiding a candidate to a successful completion of their goal of becoming an effective and caring teacher".

\subsection{Findings on the benefits of teaching practice as perceived by community members}

From the results shown in Table 4, it is clear that community members had numerous benefits from teaching practice exercise. Community members expressed that teaching practice improved their personal development through collaboration with student teachers (69.4\%). A good percentage (62.5\%) of community members said teaching practice improved reading and communicative skills and $66.7 \%$ said it improved their children academic performance through extra mural lessons by student teachers. A great proportion (71.9\%) said teaching practice brings pleasure to them by counseling student teachers while $79.4 \%$ of community members said teaching practice give satisfaction to them. This finding confirms the assertion of Kaleptwa and Igomu (2013) that teaching practice offers practicing teachers the opportunity to relate personally with school administrators, teachers and parents as they learn from each other.

In addition, $83.0 \%$ of community members said teaching practice can be of economic benefits when student teachers rent their houses and $72.2 \%$ when they buy food stuff from their local markets. Community members $78.4 \%$ and $77.8 \%$ expressed that teaching practice bring health benefits when student teachers engage community development projects by giving health talks on Acquired Immune Deficiency Syndrome (AIDS) and actively participate in environmental sanitation respectively.

\section{Conclusion}

This study showed that teaching practice has numerous benefits to the student teachers as it can improve their confidence in speaking, communication skills, improved their knowledge of teaching methods and how to keep school records, amongst others. Teaching practice has also been proved to be beneficial to mentors in such ways as giving pleasure and satisfaction to them, as well as helping to relieve some teachers off their excess workloads. The study has further established that teaching practice is beneficial to community members where the practicing schools are sited in terms of bringing academic, health and economic benefits.

\section{Recommendations}

The study recommends as follows:

1. Federal and State governments of Nigeria should provide more motivation to universities and colleges of education affiliated to them by improving secondary and primary school environments.

2. Faculties of education of tertiary education institutions should continue to foster cordial inter-personal relations with cooperating schools for better teaching practice exercise.

3. Communities in southern Nigeria should continue to cooperate with tertiary education institutions and their student teachers in a mutuality manner for continued improvement in teaching practice. 


\section{References}

Adeleke, M. A., Adesina, B. A., Salami, M. O., and Adebayo, J. A.(2011). Influence of teaching practice exercise on accidental teacher education candidates at the Obafemi Awolowo University, lle-Ife. Review of Higher Education in Africa, 3(1), 11-17.

id, M. (2001). Efficiency of a suggested program for developing Art Education student-teachers' critical thinking and its influence on the outcome of the teaching process. Studies in Curricula and Instruction, 71, 83-221.

Andabai, P. W. (2013). The impact of teaching practice on trainee teachers in the Nigerian tertiary institutions: The Niger Delta University experience. Academic Journal of Interdisciplinary Studies, 2(5), 109-116. Retrieved from www.mcseroi.org DOI: 10.5901/ajis.2012v2n5p109.

Bhagara, A. \& Pathy, M. (2011). Perception of student teachers about teaching competencies. American International Journal of Contemporary Research, 1(1), 77-81.

Bhargava, A. (2009). Teaching practice for student teachers of B.Ed programme: Issues, predicaments and suggestions. Turkish Online Journal of Distance Education, 10(2), 1-7.

Bolarfinwa, O. (2011). Effects of teaching practice on student teachers in tertiary institutions in Nigeria. GRIN E-Book Retrieved from http://www.grin.com/e-book .

Farauta, K. G. \& Amuche, C. I. (2013). Assessment of attitude of education students towards teaching practice in Nasarawa State University, Keffi, Nigeria. Journal of Education and Practice, 4(13), 181-183. Retrieved from http://www.iiste.org

Jekayinfa, A. A., Yahaya, L. A., Yusuf, A. ,Ajidagba, U.A., Oniye, A. O., Oniyangi, S. O. \& Ibraheem, T. O. (2012). Lecturer's assessment of teaching practice exercise in Nigerian universities, Journal of Education and Practice 3(4), 79-86. Retrieved from http://www.iiste.org

Kaleptwa, G. and Igomu, A. C. (2013). Assessment of attitude of education students towards teaching practice in Nasarawa State University, Keffi, Nigeria. Journal of Education and Practice, 4(13), 181-188. Retrieved from http://www.iiste.org

Katrina, M. (2004). Lessons learned: Reflecting back on student teaching. Unpublished Master Thesis. Department of Middle and Secondary Education, The Florida State University College of Education. Retrieved from http://www.etd.lib.fsu.edu

Koc, C. (2011). The views of prospective class teachers about peer assessment in teaching practice. Educational Sciences: Theory and Practice, 11(4), 1979-1989.

Mkhasibe, R. G. M. (2014). Student teachers'perceptions of teaching practice at the University of Zululand. M.Ed Dissertation, Department of Educational Psychology and Special Needs, University of Zululand. Retrieved from www.uzspace.uzulu.ac

Nakpodia, E. D. (2011). Teacher and the student practice teaching programme in Nigeria education system.. International Journal of Educational Administration and Policy Studies, 2(3), 33-39.

Ogonor, B. O and Badmus, M. M. (2006). Reflective teaching practice among student teachers: The case of tertiary institutions in Nigeria. Australian Journal of Teacher Education, 31(2), 1-11.

Olulobe, N. P. (2007). Teacher education, school effectiveness and improvement. Unpublished doctoral thesis, University of Helsinki, Finland.

Ogunbameru, M. T \& Uwameiye, R. (2012). Reflective practice: A strategy for improving teaching practice in Nigerian Colleges of Education. International Journal of Academic Research in Progressive Education, 1(4), 282-294. Retrieved from www.hrmars.com/adm/pics/1331.pdf

Putnam, R. T. and Borko, H. (2000). What do reviews of knowledge and thinking have to say about research on teacher learning? Educational Researcher, 29(1), 4-15.

Rajuan, M. (2008). Student teachers' perceptions of learning to teach as a basis for supervision of the mentoring relationship. Eindhoven: Eindhoven University of Technology Library.

Taneja, R. P. (2000). Encyclopedia of comparative education 4, New Delhi: Anmol Publications Ltd.

Tschannen, M. and Woolfolk, H. (2007). Teacher efficacy to student teachers in the Faculty of Education Elbsan Albania, Journal of Education and Social Research.

Vygotsky, L (1978). Social constructivism (chapter 6). In R. Jackson \& G. Sorensen (3rd Ed), "Introduction to international Relations: Theories and Approaches". London: Harvard University Press.

Wambugu, P., Barmao, A. \& Ng'eno, J. (2013). Student teachers' perceptions of teaching practice assessment in Egerton University, Kenya. Education Journal, 2(4), 169-175. Retrieved from http://www.sciencepublishinggroup.com/j/edu Doi:10.11648/jedu20130204.20

Wenzlaff, T.L. and Weseman, K. C. (2004). Teachers need teachers to grow. Teacher Education Quaterly, 31(2), 203. Retrieved from www.teqjournal.org -

Young, R. B. \& Edwards, M. G. (2006). A comparison of student teachers perception of important elements of the students teaching experience before and after a twelve weeks field experience. Journal of Agriculture Education, 47(3), 11.26. 